\title{
Stock Price Reaction to the Stock Splits Announcement of Listed Companies in the Colombo Stock Exchange
}

\section{W. S. S Soyza}

Wayamba University, Sri Lanka

\author{
K. A. S. S. Kodithuwakku \\ Wayamba University, Sri Lanka
}

\section{S.M.R.K. Samarakoon}

Wayamba University, Sri Lanka

\begin{abstract}
A stock split is a corporate event that directly impacts the number of a company's shares and indirectly on stock prices. This study tests the effect of the stock splits on the share price of companies listed in the Colombo Stock Exchange during the periods of pre and post stock split announcement in accordance with the Efficient Market Hypothesis. The main objective of this paper is to identify the overall impact of a stock split announcement on stock prices. This study analyses 88 annual stock splits during the ten (10) year period from 2009 to 2019 by taking the listed companies in the Colombo Stock Exchange into consideration. It uses the event study methodology to test the market efficiency of the Colombo Stock Exchange, and the market model is run with the aid of abnormal returns, which are calculated based on daily closing stock prices and the All-Share Price Index. For analysing the results, the graphical analysis and tstatistics have been utilized. According to the event day average abnormal return, the majority of stock splits were more negative than positive with a significant $t$ value at $5 \%$ by indicating that investors were taking the stock split announcement as bad news just after the split announcement was released. Each day with a significant Average Abnormal Return shows more positives than negatives. Graphical results have shown both Average Abnormal Return, and Cumulative Average
\end{abstract}


Abnormal Return has remained continuously negative up to 18 and 25 days, respectively, by implicating that stock splits have made a deleterious impact on stock return. This study finally concludes that the information regarding the stock splits has not been absorbed efficiently by the market because the market reactions before and after the date of the split announcement were significant at $5 \%$, although the Average Abnormal Return got a quick reaction to the announcement. Furthermore, results had not provided evidence for Semi-Strong Form efficiency of the Colombo Stock Exchange since the significant stock price adjustments before and after the event day was noticed. By this study, the policymakers and investors are convinced that all information has not been incorporated into stock prices in making their decisions.

\section{Keywords:}

Efficient market hypothesis, Event study methodology, Signalling theory, Sri Lanka, Stock splits

\section{Introduction}

A stock split is a corporate activity where the company divides each of its shares into a fixed percentage that concurrently diminishes the share price. In simple terms, the stock split means the company splits the majority share into several shares. As a result of splitting stock, the number of outstanding shares gets reduced without creating or loosening the market capitalization of the company. Inversely, a split-back stock or reverse split is a process through which corporate stock shares are effectively merged to form a smaller number of proportionally more valuable shares, and it is called a merger of stocks. When considering a stock split, the stock price is one of the fundamental criteria to be considered because the price of a stock means the highest amount that someone is willing to pay for the stock or the lowest amount that they can buy. There are a number of technically accepted methods in determining the stock price, while the Initial Public Offering (IPO) is one of the generally accepted techniques among them which is used to determine the price of a share at the very first time. The Colombo Stock Exchange (CSE) has introduced several price indices such as All Share Price Index (ASPI), and Standard \& Poor's Sri Lanka 20 (S\&P SL20). ASPI is used to calculate share price change in all listed companies and S\&P SL20 based on market capitalization following the results of 20 leading publicly traded companies listed in the CSE. This study is mainly concerns how an announcing of stock splits impacts stock returns and how it becomes 
important to an increment in the number of listed companies regarding stock splits in 2010. Indeed, a stock split has been accompanied by the stock price of the relevant company, which has been proved econometrically, psychologically, and financially by a number of pieces of literature.

Generally, companies use the splitting of stocks as the most advantageous tool on the side of the company as well as the management. Marks (2006) suggests that the investors are affected psychologically by the principle of the stock split when shares are undervalued or overvalued. That means if the stock were undervalued, shareholders are more likely to buy shares because additional returns can be earned through the trading investor, whereas if the share price is overvalued, the share is more likely to be sold. Therefore, knowledge of share price assists the investor in making the best decision in investing in the more beneficial companies. Since share price reflects all information, an investor can determine whether a stock is overvalued or undervalued and therefore invest accordingly. On the other side, the management used the market split roughly to increase the demand for the share. Additionally, Fama (1969) suggests that if the stock prices adjust to new information quickly, the market is efficient, and Fama (1970) describes the theory of market efficiency when the prices reflect all the publicly available information. So, this study concerns to seek out the problem that states whether the share prices of listed companies are affected by the announcements of stock split. Although the number of previous studies which are included in the literature review has observed the impact of stock splits on the distribution of stock returns, retention ratio, stock return volatility etc., this study allows to study on how a stock split announcement affects the market price of a share and the efficiency by using event study methodology.

This study has aimed at several research objectives that lead to inspecting the stock price reaction to the stock split announcement in companies listed in the CSE. In addition, the study supports recognizing the stock price fluctuation in the CSE during the pre and post stock split announcement period and understanding the overall effect of a stock split on the market efficiency. Therefore, the objectives of the study are investigating the stock price response to the stock split of listed companies in the CSE and identifying whether there is any abnormal return around the stock split announcement date of the stock split. Accordingly, the following hypotheses are developed.

Hypothesis 1: There is no significant impact on stock prices around the stock split announcement date of the stock split. 
Hypothesis 2: There is no abnormal return around the stock split announcement date of the stock split.

\section{Literature Review}

Hua \& Ramesh (2013) investigated stock split announcements and their effects on stock prices in the Colombo Stock Exchange (CSE) to analyse how stock prices respond to stock split announcements as well as the market performance by monitoring the CSE using a 64-events sample regarding 52 companies selected from 14 industries during the period from 2009 to 2012. This reading shows that stock splits in the selected companies had a substantial signal and information quality, and by endorsing the signalling theory, the market has responded favourably to the announcement. The researchers concluded that the results of their study support the Semi Strong Form Efficiency because the stock prices are so quickly adapting to public information that no buyer will earn an abnormal return through the split stock.

Dharmarathne (2019) examined the impact of information aroused from the right issue announcement on the CSE with the aim of observing the efficiency of the CSE when the right issue information was just released to the market in accordance with mainly the Semi - Strong Form Efficiency. In generating abnormal returns, the Mean Adjusted Return Model, Market Adjusted Return Model and Market Model have been used while several time series models also have been used. The findings have concluded that stock price reacted adversely after the announcement of the right issue, and the CSE is inconsistent with information efficiency due to the delayed price reactions.

Agara (2014) also explored a parallel analysis of the previous research to study the impact of stock split on stock returns among companies using even the study technique and the market model used to calculate the irregular stock return during the study periods. The researchers state that incoming retail investors would find new rates more appealing. The new price is more appropriate for satisfying the current shareholder as well. It can be demonstrated by the social pricing strategy. Share price knowledge and its momentum help investors in selecting the companies in which to invest prudently. With respect to the signalling theory, this result indicates that stock return has a significantly positive effect on the stock split effect.

Desai et al. (1997) have examined the impact of the shifts in stock split trading activity on the share price and adverse information part of the bid request spread and found a significant rise in variability after splitting, while Fernando et al. 
(1999) concluded that an announcement of the stock split might convey favourable information to the market. However, if managers have negative information on future growth because of the costs involved with stock splits and stock dividends, they may choose not to increase the number of shares (split).

Dharmarthna and Amarasekera (2016) have observed the Stock Price Reaction to the Stock Split Announcements and Information Efficiency of the CSE by using Event Study Methodology. With the assistance of Mean Adjusted Return Model, Market Adjusted Model, Market Model and Time Series Models, their observation concludes that the share price does not reflect the information fully and instantaneously, and it does not provide evidence for the Semi-Strong Form Efficient Market Hypothesis because negative price reactions could be noticed before and after the Stock Split.

This hypothesis explains that if the share price is within the optimal price range, the investor is encouraged to buy the share, which leads to increase liquidity. Although numerous researchers have applied different methods for measuring the stock's liquidity, such as Ask-Bid Spread, Share Price Volatility, Trading Volume, Volume Ratio, and Dollar Volume, the event study methodology is also identified as a better method for analysing the liquidity effect. Accordingly, Gunathilaka (2011) has examined the impact of stock split on liquidity by using a sample of 40 stock splits announcement by companies listed in the Colombo Stock Exchange during the period from 2007 to 2010 through an event study methodology and cross-sectional regression technique. The cumulative abnormal return is identified as the dependent variable, and the size of the stock is split as a dummy variable to measuring the impact of signalling on market liquidity, while the market liquidity, which it identifies as the independent variable. This research has used the return on the first price of the day between days 0 and 1 . The study discovers a significant positive market reaction and a significant explanatory power of the announcement effect on liquidity at the stock split.

Patel, Dave, \& Shah (2016) attempted to examine the stock market and trading volume reaction concerning the information content of the event stock split announcement for 34 selected companies who announced stock split in 2016. The study also included a volume ratio analysis to check whether the stock split announcement has a significant impact on the trading volume of a particular stock. The reading specifies that the liquidity of the Indian stock market is adversely responding to the stock split implementation. Because the volume ratio decreases after the stock split announcement, this result contradicts the 
other findings. For example, Huang, Liano and Pan (2007) have found that there is an inverse relationship between the stock split announcement and the operational results over the four years following the announcement, whereas Garcia de Andoain (2009) has found that the company's stock split announcements had no impact on the stock price on the announcement day. Results support the semi-strong form of the efficient market hypothesis since stock prices adjust to public information so quickly that no investor can earn an abnormal return by trading on the announcement day.

The event study methodology is useful for identifying the impact on share price, market reaction to some particular event in the market or economy. An event study analyses the impact of a specific piece of news or event directly or indirectly on a company and its stock. Mackinlay (1997), Brown and Warner (1985) have observed the event study methodology practically with proper guidance on conducting an event study. According to studies, it is important to identify the event date; it is denoted as $t_{0}$, which may be the stock split date of the announcement, stock split ex-date, dividend announcement date, merger and acquisition date, and also can be a war-ending date, etc. For example, Chaudhary, Hashmi, \& Younis (2016) examine the signalling effect on the cash dividend announcement among the companies listed in the Karachi Stock Exchange during 2010. To recognize the influence on the cash dividend announcement upon stock return, the event window of 15 days consisting of 7 days prior, and 7-day post the event date, the dividend announcement date has been used. The result supposes that the average abnormal return remains positive and statistically significant in the post-event window period.

The dividend announcement and stock split announcement can research to investigate the market reaction on the right issues, and bonus issues implemented by the companies. Hua \& Ramesh (2013) have exercised the investigation to identify the market reaction to right issue announcements and a test of market efficiency in the Colombo Stock Exchange (CSE) by employing event study methodology. The sample was contained 78 events (61 companies) from different sectors of the CSE during the period 2008 to 2012. And it concluded that there is a strong positive impact on stock prices by the right issue and significant information content in the CSE. 


\section{Methodology}

\section{Research Design}

This study is based on the Event Study Methodology in order to carry out an analysis of the stock market response of selected stock splits. The focused populations consist of all the stock splits executed by 71 companies listed in the CSE from 2009 to 2019. However, the sample of this study is 88 stock splits, selected out of 94 total stock splits that occurred from 2009 to 2019. The sample selection is based on the availability of the information, such as the handiness of executing the date of the stock split. Data for the study, including stock split data, daily share prices, daily All Share Price Index (ASPI) data, stock turnover, Number of traders, and Number of shares traded, are extracted from the CSE data library.

As per the Event Study Methodology, several terms should be identified in accordance with the analysis. At first, the event/s should be specified, which is/are going to be analysed. This study concerns the stock splits that took place within the sample period as the event. Therefore, the event date is when the stock split took place, which is termed as $t_{0}$. Figure 2 shows the event timeline specified for the study, which comprises the event window, the estimation window, and the event date. The reason for selecting this approach is, it has allowed analysing the stock market response to an event to be prudently correlated by looking at such incident results that happened in the event earlier and later. Further, the signalling effect of a stock split is analysed by examining the pre-event window and the post-event window in addition to the examination of the event day.

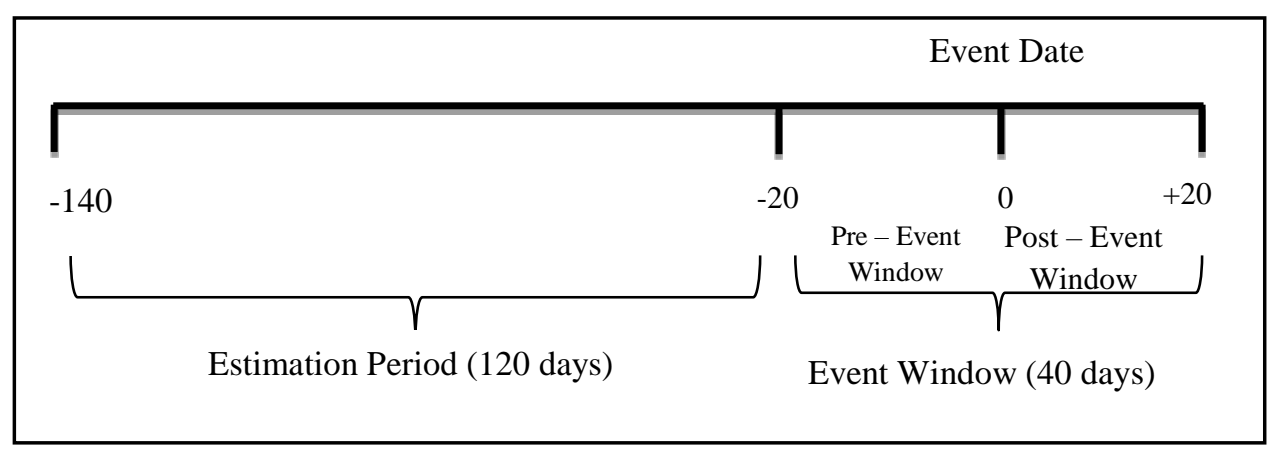

Figure 1: Event Timeline 
To carry out an event study, the event date is ex-date $(t=0)$, the event window is 40 days consisting of 20 days before the event date and 20 days after the event date $(t=-20 \&+20)$. Further, this study was applied to the market model to estimate the parameters, which are the alpha $(\alpha)$ and beta $(\beta)$. The study applies the estimation period of 120 trading days starting from the $t=-21$ day to $t=-140$ days.

Table 1 shows the population of yearly stock split announcements from 2009 to 2019 , which is considered by this study. This study focuses only on 88 stock splits out of the following 94 stock splits.

Table 1: Year-wise stock splits

\begin{tabular}{cc}
\hline Number of splits & $\begin{array}{l}\text { Total } \\
\text { events }\end{array}$
\end{tabular}

\begin{tabular}{lcccccccccccc}
\hline $\begin{array}{l}\text { Split } \\
\text { Ratio }\end{array}$ & $\mathbf{2 0 1 9}$ & $\mathbf{2 0 1 8}$ & $\mathbf{2 0 1 7}$ & $\mathbf{2 0 1 6}$ & $\mathbf{2 0 1 5}$ & $\mathbf{2 0 1 4}$ & $\mathbf{2 0 1 3}$ & $\mathbf{2 0 1 2}$ & $\mathbf{2 0 1 1}$ & $\mathbf{2 0 1 0}$ & $\mathbf{2 0 0 9}$ & \\
\hline $\begin{array}{l}\text { Ten for } \\
\text { one }\end{array}$ & - & 1 & - & 5 & 3 & - & - & 1 & 4 & 8 & 2 & $\mathbf{2 4}$ \\
$\begin{array}{l}\text { Two for } \\
\text { one }\end{array}$ & - & - & 1 & 4 & 2 & - & 2 & 1 & 11 & 7 & 1 & $\mathbf{2 9}$ \\
$\begin{array}{l}\text { Five for } \\
\text { one }\end{array}$ & 1 & - & 1 & - & 1 & - & - & - & 5 & 5 & - & $\mathbf{1 3}$ \\
$\begin{array}{l}\text { Three } \\
\text { for one }\end{array}$ & - & - & 1 & - & - & - & - & - & 2 & 3 & - & $\mathbf{6}$ \\
$\begin{array}{l}\text { Others } \\
\text { Entire }\end{array}$ & - & 1 & 1 & 1 & 3 & 1 & 1 & 2 & 5 & 7 & - & $\mathbf{2 2}$ \\
\multicolumn{1}{l}{ sample } & & $\mathbf{2}$ & $\mathbf{4}$ & $\mathbf{1 0}$ & $\mathbf{9}$ & $\mathbf{1}$ & $\mathbf{3}$ & $\mathbf{4}$ & $\mathbf{2 7}$ & $\mathbf{3 0}$ & $\mathbf{3}$ & $\mathbf{9 4}$ \\
\hline
\end{tabular}

The Event Study Methodology involves finding Abnormal Returns for each stock in the sample by employing Equation 4 through the difference between Actual Return and Expected Return. Equation 1 is reflected in the Market Model under the Event Study Methodology, which can be applied for taking the Expected Return for $\mathrm{i}^{\text {th }}$ security. The Actual Return of security is taken from Equation 2, while the market return is calculated from Equation 3. Next, when the Abnormal Return for each stock is aggregated across securities, the daily Average Abnormal Returns (AAR) can be obtained as per Equation 5, and when the AARs are aggregated across the time, the Cumulative Average Abnormal 
Return (CAAR) can be taken as per Equation 7. Ultimately, for testing the significance of AAR, $\mathrm{t}$ statistic is used as per Equation 6.

$E\left(R_{i t}\right)=\alpha i+\beta_{i} R_{m t}$

Where;

$\mathrm{R}_{\mathrm{it}}=$ the rate of a return of stock " $\mathrm{i}$ " on the day " $\mathrm{t}$ " in the window period,

$\mathrm{R}_{\mathrm{mt}}=$ the rate of actual return on the market on the day "t,"

$\alpha=$ the intercept term (alpha coefficient) of security "i",

$\beta_{\mathrm{i}}=$ slope of a straight line (beta coefficient) of stock " $i$ " and

$\mathrm{e}_{\mathrm{it}}=$ regression error term of security " $\mathrm{i}$ " on the day " $\mathrm{t}$ ".

$R_{i t}=\frac{P_{i t}-P_{i t-1}}{P_{i t-1}}$

Where;

$\mathrm{R}_{\mathrm{it}}=$ the rate of a return of stock " $\mathrm{i}$ " on the day " $\mathrm{t}$ " in the window period,

$\mathrm{P}_{\mathrm{it}} \quad=$ market closing price per share " $\mathrm{i}$ " on day " $\mathrm{t}$ "

$\mathrm{P}_{\mathrm{it}-1}=$ market closing price per share " $\mathrm{i}$ " on the day " $\mathrm{t}-1$ ".

$R_{m t}=\left(I_{t}-I_{t-1}\right) / I_{t-1}$

Where;

$\mathrm{Rmt}=$ the rate of actual return on the market on the day " $t$ ",

$\mathrm{I}_{\mathrm{t}} \quad=$ ASPI on the day " $\mathrm{t}$ " and

$\mathrm{I}_{\mathrm{I}-\mathrm{t}}=$ ASPI on the day "t-1".

$A R_{i t}=R_{i t}-E\left(R_{i t}\right)$

$\mathrm{AR}_{\text {it }}=$ abnormal returns for a firm " $\mathrm{i}$ " at the time " $\mathrm{t}$ ",

$\mathrm{R}_{\mathrm{it}} \quad=$ the rate of the actual return of stock " $\mathrm{i}$ " on the day " $\mathrm{t}$ " in the window period and

$\mathrm{E}\left(\mathrm{R}_{\mathrm{it}}\right)=$ expected normal returns for the firm " $\mathrm{i}$ " at a time " $\mathrm{t}$ " in the window period.

$A A R_{t}=\frac{1}{N} \sum_{i-t}^{N} A R_{i t}$

Where;

AARt $=$ average abnormal return for day " $t$ " in the window period,

$\mathrm{N} \quad=$ number of events in the sample.

$T\left(A A R_{t}\right)=A A R_{t} / \sigma\left(A A R_{t}\right.$

Where;

$\mathrm{T}\left(\mathrm{AAR}_{\mathrm{t}}\right)=$ Calculated $\mathrm{t}$ value $(\mathrm{AAR})$,

$\mathrm{AAR}_{\mathrm{t}}=$ average abnormal return on day " $\mathrm{t}$ " and

$\alpha=$ standard deviation of $\mathrm{AAR}_{\mathrm{t}}$.

$C A A R_{t}=\sum_{i-t}^{T} A A R_{t}$

Where;

$\mathrm{CAAR}_{\mathrm{t}}=$ cumulative average abnormal return on the day " $\mathrm{t} "$ 


\section{Results}

The data obtained from CSE covers ten years between 2009 and 2019, with 88 stock splits. By establishing the relationship between stock splitting and share prices, the analysis is conducted using Excel data sheets in order to evaluate the abnormal returns under the event study methodology with reference to the Market Model. The analysis section of this study comprises the event study analysis in a graphical presentation and the $\mathrm{t}$ - statistical analysis to grab a valid and reliable conclusion regarding the research problem.

\section{Graphical Analysis}

Figure 3 shows that both AARs and CAARs have remained constant with minority fluctuations with positive and negative values within the $-140,-20$ window. It implies that the market anticipates stock split announcements as favourable information about the future of the firm since the majority of points had got positive before the event happened. However, both AAR and CAAR have shown a sudden drop by the Event date on which the announcement of the stock split was made by implying that the ability of stock prices to reflect the

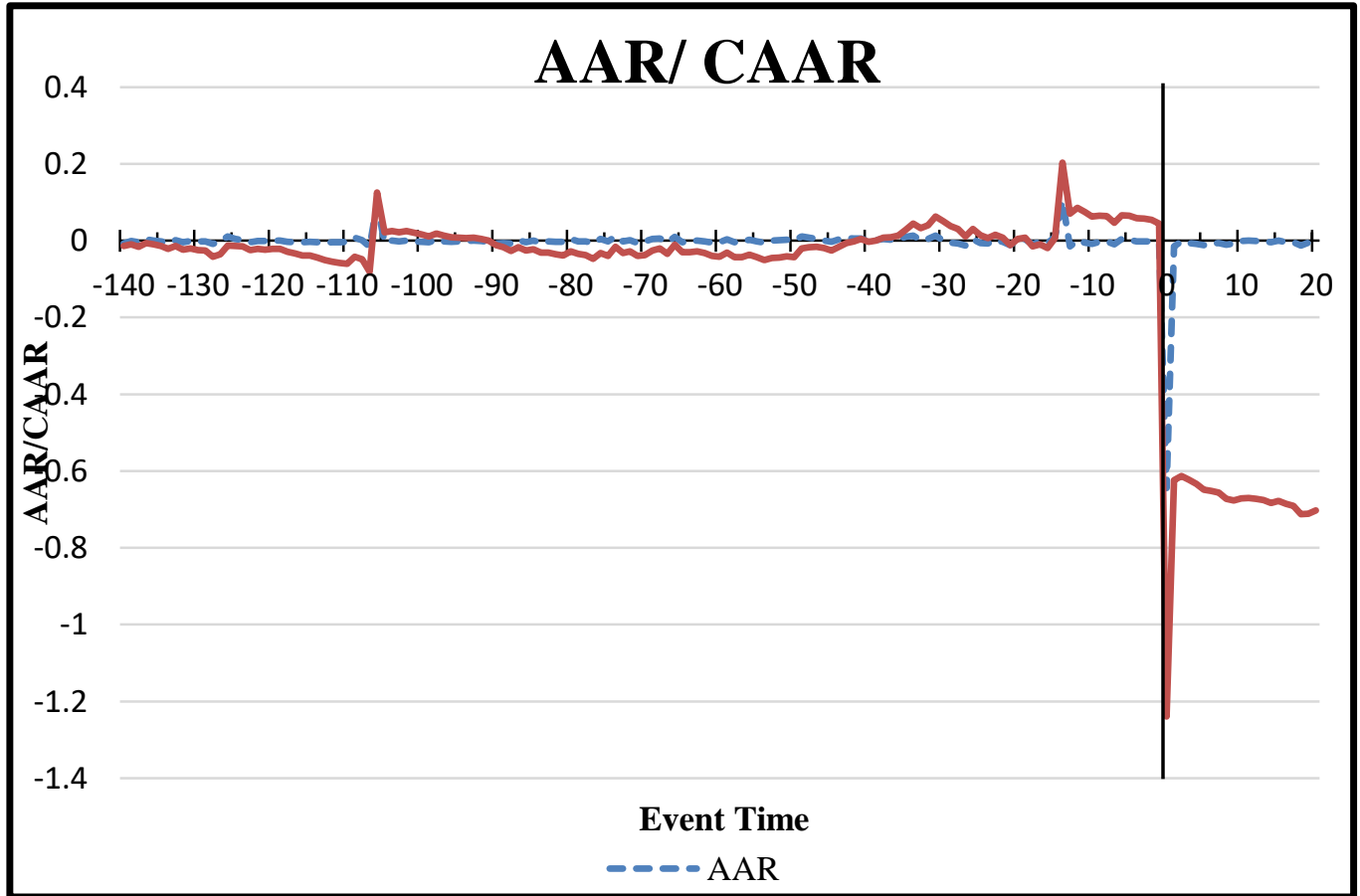

Figure 2: AAR and CAAR for Estimation Window (-140, -20) and Event Window (-20, +20) 
new information as soon as it was released to the market.

Figure 4 shows the exact reaction during the Event window with the closest view. Although the AAR results show a positive situation before the event date, a quick drop has happened in both AAR and CAAR as well as, it has got negative. However, by the day +1 , abnormal returns began to rise accordingly but keeping its negativity as it is. The continuous adverse behaviour in AAR and CAAR lasted 18 days after the event date by implying that the stock split has made a deleterious impact on stock return. Overall, CAARs were negative. for 25 days, including the event day during the event window.

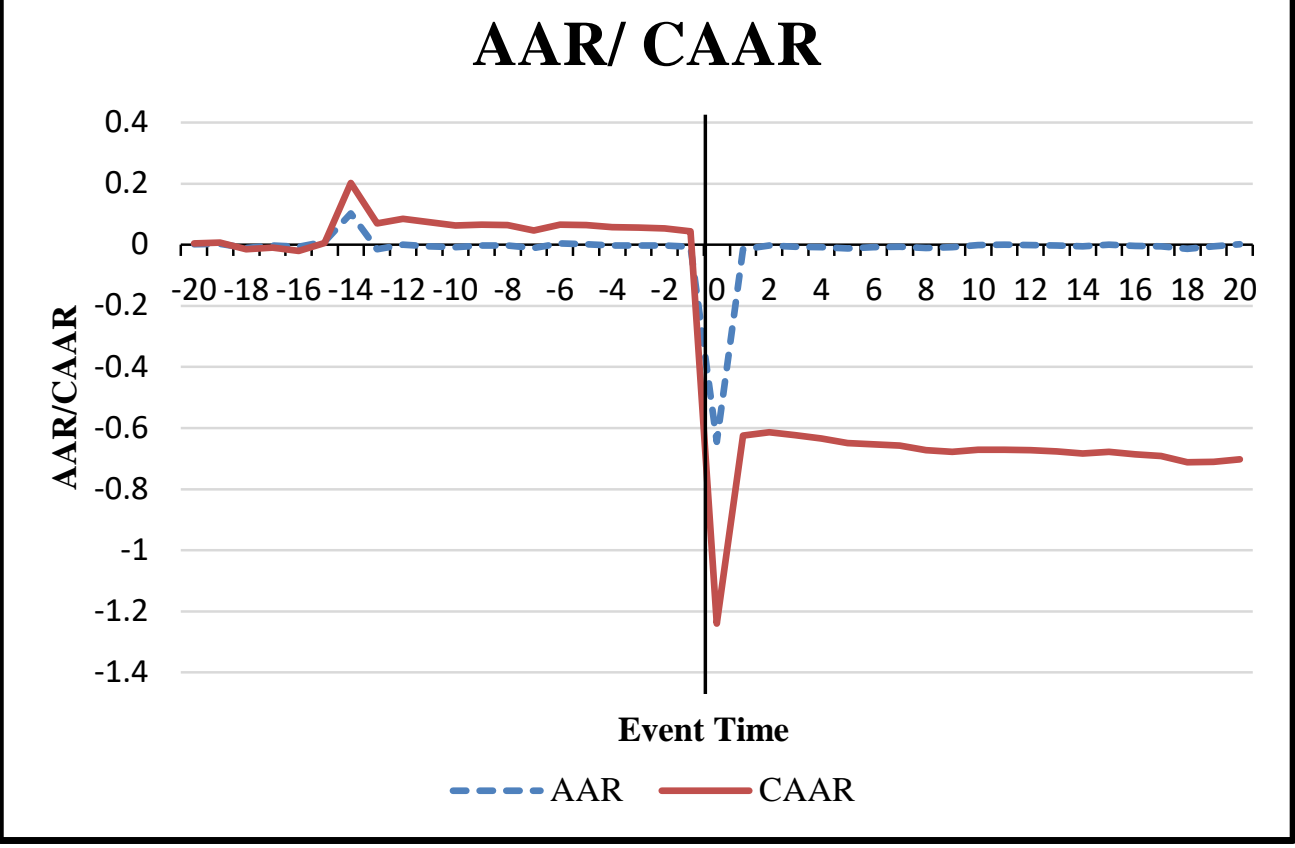

Figure 3: AAR and CAAR for Event Window $(-20,+20)$

\section{t-Statistics Analysis}

Table 1 presents the AARs, CAARs during the Event Window, as well as the $\mathrm{t}$ Statistic value of AARs has been shown in order to find the significance of each day. An asterisk shows the significance of AAR under a 95\% confidence level. In addition to that, an analysis is carried out to check how many events were positive and negative in each day out of the total sample, which is summarized under the column plus: minus sign. 
Table 2: AAR, CAAR, $t$-Statistics and Sign for the overall sample

\begin{tabular}{|c|c|c|c|c|c|}
\hline $\begin{array}{l}\text { Event } \\
\text { date }\end{array}$ & $\begin{array}{l}\mathrm{AARs}^{1} \\
\%\end{array}$ & $\begin{array}{l}\text { CAARs }^{2} \\
\%\end{array}$ & T(AARs) ${ }^{3}$ & Sig $^{4}$ & $\begin{array}{l}\text { Sign }^{5} \\
(+:-)\end{array}$ \\
\hline $\mathrm{N}$ & 0.002028732 & 0.002040142 & 0.457368773 & & $50: 38$ \\
\hline-19 & 0.002840929 & 0.004881071 & 0.350737748 & & $35: 53$ \\
\hline-18 & -0.009974907 & -0.005093836 & -1.273246595 & & $30: 58$ \\
\hline-17 & -0.002222547 & -0.007316383 & -0.532290752 & & $39: 49$ \\
\hline-16 & -0.006174015 & -0.013490398 & -1.279862687 & & $41: 47$ \\
\hline-15 & 0.009783652 & -0.003706746 & 1.249265053 & & $46: 42$ \\
\hline-14 & 0.103163599 & 0.099456853 & 0.690921492 & & $42: 46$ \\
\hline-13 & -0.014626841 & 0.084830013 & -0.911135813 & & $31: 57$ \\
\hline-12 & 0.000264934 & 0.085094947 & 0.039556506 & & $42: 46$ \\
\hline-11 & -0.005351454 & 0.079743493 & -1.075610117 & & $37: 51$ \\
\hline-10 & -0.008473192 & 0.071270301 & -1.409591419 & & $38: 50$ \\
\hline-9 & -0.002922973 & 0.068347328 & -0.626344561 & & $42: 46$ \\
\hline-8 & -0.002096953 & 0.066250376 & -0.525847895 & & $41: 47$ \\
\hline-7 & -0.009926042 & 0.056324334 & -1.18471171 & $*$ & $32: 56$ \\
\hline-6 & 0.004648682 & 0.060973015 & 0.259215018 & & $37: 51$ \\
\hline-5 & 0.001991658 & 0.062964673 & 0.491551648 & & $54: 34$ \\
\hline-4 & -0.002431522 & 0.060533151 & -0.596237057 & & $34: 54$ \\
\hline-3 & -0.001818206 & 0.058714945 & -0.559262357 & & $37: 51$ \\
\hline-2 & -0.002480137 & 0.056234808 & -1.302687057 & & $34: 54$ \\
\hline-1 & -0.006122684 & 0.050112124 & -2.497044331 & $*$ & $31: 57$ \\
\hline 0 & -0.644978166 & -0.594866042 & -15.60123002 & $*$ & $2: 86$ \\
\hline 1 & -0.014686275 & -0.609552316 & -1.927965267 & $*$ & $28: 60$ \\
\hline 2 & -0.001748621 & -0.611300937 & -0.234558938 & & $36: 52$ \\
\hline 3 & -0.005893383 & -0.61719432 & -1.026314014 & & $34: 54$ \\
\hline 4 & -0.008129192 & -0.625323512 & -1.430491249 & & $37: 51$ \\
\hline 5 & -0.011911309 & -0.637234822 & -2.230716664 & & $30: 58$ \\
\hline 6 & -0.007662412 & -0.644897234 & -1.999475474 & $*$ & $33: 55$ \\
\hline 7 & -0.005880152 & -0.650777386 & -1.041215901 & & $36: 52$ \\
\hline 8 & -0.010935438 & -0.661712824 & -1.858080707 & & $31: 57$ \\
\hline 9 & -0.007761138 & -0.669473962 & -1.930025626 & & $30: 58$ \\
\hline 10 & -0.000769953 & -0.670243915 & -0.14193454 & & $36: 52$ \\
\hline 11 & $-7.70493 \mathrm{E}-05$ & -0.670320965 & -0.010944371 & & $34: 54$ \\
\hline 12 & -0.000900882 & -0.671221846 & -0.18028 & & $34: 54$ \\
\hline 13 & -0.002535995 & -0.673757841 & -0.68581 & & $40: 48$ \\
\hline 14 & -0.004585967 & -0.678343808 & -0.83497 & & $36: 52$ \\
\hline 15 & 0.000296384 & -0.678047425 & 0.087428 & & $42: 46$ \\
\hline 16 & -0.003940307 & -0.681987732 & -0.86026 & & $33: 55$ \\
\hline 17 & -0.004554598 & -0.68654233 & -0.66278 & & $28: 60$ \\
\hline
\end{tabular}




\begin{tabular}{lllll}
18 & -0.012883125 & -0.699425455 & -1.71835 & $27: 61$ \\
19 & -0.005781529 & -0.705206985 & -1.15054 & $34: 54$ \\
20 & 0.001419844 & -0.703787141 & 0.187731 & $38: 50$ \\
\hline \multicolumn{5}{c}{$*$ Significant at 5\% } \\
Notes: ${ }^{1}$ Daily average abnormal returns \\
${ }^{2}$ Daily cumulative average abnormal returns \\
${ }^{3}$ t - statistic of daily average abnormal returns \\
${ }^{4}$ Significance of average abnormal returns ${ }^{*}$ Significant at 5\% \\
${ }^{5}$ Number of Positive stock splits to number of negative stock splits \\
\hline
\end{tabular}

Although AARs around the event day fluctuate among positive and negative ends, most of the AARs are negative than positive AARs during both pre and post the event day. In detail, $35 \%$ of results on which 7 days before the event day and $10 \%$ on which 2 days after the event day were positive while $65 \%$ on which 13 days before and $90 \%$ on which 18 days after the event day had been found as negative. The AARs in Post - Event period were higher than the Pre Event period, and negative returns are also observed. From the entire sample of 88 stock split execution, there are 2 positive responses and 86 adverse responses on the event day. The number of positive versus negative sign is 31:57 on the event day and 28:60 on day 1. Especially, this result indicates that the AAR on day 0 is $0.6449 \%$, which is negative and statistically significant. Since hypothesis 1 is rejected and implied, there is a significant impact around the day of the stock split announcement. And also, Table 3 indicates that only $2 \%$ of the days generate positive abnormal returns, and $86 \%$ of the days generate negative abnormal returns. It implies that Stock prices are affected adversely by the stock split. This finding is consistent with the work of Patel, Dave and Shah (2016) who observed that the Indian Stock Market has been negatively affected by the information content of the stock split announcement. However, the Indian stock market has been recognized as an efficient market regarding stock split announcement since it does not allow investors to earn abnormal returns during the event period.

In accordance with the significance test, 5\% of a significant level is applied. Accordingly, the highest significant negative AARs of $-0.01468 \%$ is found on day +1 , which implies that the market has responded negatively on the first day after the announcement due to bad signals absorbed by the market. And also, the statistical significance at the $5 \%$ level is denoting the return as negative on average during the immediate day after the event day at $95 \%$ of the chance. In 
addition to that, AAR generates a negative abnormal return of $-0.00766 \%$ on day +6 , and it is also statistically significant. Therefore, Hypothesis 2 can be rejected since significant abnormal returns around the day of the stock split announcement.

And also, these findings of the event day significance confirm the findings of Hua and Ramesh (2013). The information content of a stock split is absorbed by the stock market on the date of the stock split announcement. However, this study is inconsistent with their opinion since significant abnormal returns can be identified before and after the stock split announcement day.

Table 3: Direction of Abnormal Returns (ARs) on Day 0

\begin{tabular}{lcc}
\hline Direction & Number of events $^{2}$ & Percentage of events $^{\mathbf{1}}$ \\
\hline Positive & 2 & $2.2 \%$ \\
Negative & 86 & $97.8 \%$ \\
Total Events & 88 & 100 \\
\hline
\end{tabular}

${ }^{\mathrm{T}}$ Number of events categorized according to the positivity or negativity of abnormal returns earned by a stock split.

${ }^{2}$ Number of events as a percentage according to the positivity or negativity of abnormal returns earned by a stock split.

\section{Discussion and Conclusion}

A stock split is a corporate action in which a corporation divides each of its shares in a fixed percentage and concurrently a diminution of the price of a share. Therefore, the stock split increases the share outstanding and does not generate or destroy market capitalization. The theoretical background indicates that most companies are executing the stock split to reduce the share price. Therefore, this study fills the knowledge gaps on the effect of stock split on the share price of firms listed in the CSE to investigate the stock price response on the stock split. To examine the relationship between a stock split and share price return, this study analyses the abnormality of the return of the share price as consistent with the Market Model by using the Event Study Methodology. The findings of this study found that on the event day, which represents the day of announcing the split significant market reactions have taken place. The information of the stock split is absorbed and adjusted by the market on the 
event day (Day "0"), indicating information efficiency since the quick drop in AAR and CAAR happened on Event Day. The empirical results of the event day provide statistically significant at 5\% level and provide evidence for the information efficiency. Results support the semi-strong form efficient market hypothesis since stock prices adjust to public information quickly, and the investor will not be able to earn a normal return by trading on the announcement day.

In accordance with the positive vs negative analysis, $22 \%$ of days were positive, and $78 \%$ of days were negative within the overall 41 days' event window, whereas $90 \%$ of dates generated a negative abnormal return after the announcement of Stock Splits were made. This indicates that most of the days earned negative AARs around the date of the stock split announcement. All of these results support that the stock split and generate a negative abnormal return and help in predicting future returns and market efficiency.

The above results indicate that the AARs are positive for the date of the stock split announcement. The survey of the Colombo Stock Exchange firms is not a semi-strong type of productive market because the market has responded before and after the announcement of stock split released to the market. Nevertheless, capital market performance relies not only on historical values, public and private records but also on applying the current stock market rules and regulations and their administrative effectiveness. As per the first objective of this study, the stock splits are investigated to catch the response on the stock prices. A negative and insignificant AAR of $0.6449 \%$ on the split execution date indicates that the market reacts negatively as well as significantly on the split announcement on execution day. Therefore, the results conclude that share prices have negatively reacted to stock splits, and share prices do not fully reflect the information arouse from the stock split announcement because of significant stock price reactions before the ex-date. The second objective of the study is to identify whether there is no abnormal return around the stock split announcement date of stock split and around the stock split day. There is evidence of a negative anticipatory effect due to adverse perceptions of investors during the pre-announcement period $(-20,-1)$ and also large negative AARs $(-7.7 \%)$ are observed during the post-announcement period of $(0,20)$ due to quick adjustment of investors to the information and a less amount of time passes to fully incorporate relevant information in the split announcement by the stock prices. However, results indicate a possibility of generating abnormal 
returns within pre and post stock split announcement day inconsistent with the semi-strong form efficiency.

All in all, using an event study methodology, the study found that the investors gain significant returns on the announcement date and a few days around the announcement dates of the stock split. Results show that stock split announcements lead to more negative abnormal returns and help in predicting future returns and market efficiency. So, this study concludes that, although the investors cannot earn abnormal returns by trading in the stocks on the stock split execution, there is a possibility of outperforming by investors.

\section{Declaration of Conflicting Interests}

The authors declared no potential conflicts of interest with respect to the research, authorship, and publication of this article.

\section{References}

Agara, B., 2014. The effect of stock split on share prices of companies listed at the Nairobi securities exchange (Doctoral dissertation, University of Nairobi).

Brown, S.J. and Warner, J.B., 1985. Using daily stock returns: The case of event studies. Journal of financial economics, 14(1), pp.3-31.

Chaudhary, G., Hashmi, S.H. and Younis, A., 2016. Does Dividend announcement generate market signal? Evidence from Pakistan. International Journal of Economics and Financial Issues, 6(1), pp.65-72.

Dharmarthne, D., 2019. Chapter Nineteen Stock Price Reaction to Rights Issue Announcements and Information Efficiency in the Colombo Stock Exchange (CSE). Managerial Dilemmas in Developing Countries: Business, Marketing, Finance and Tourism, p.229.

Desai, H. and Jain, P.C., 1997. Long-run common stock returns following stock splits and reverse splits. The Journal of Business, 70(3), pp.409-433.

Dharmarthna, D.G., Amarasekera, C., 2016. Stock Price Reactions to The Stock Split Announcements and lnformation Efficiency in Sri Lankan Capital Market. Journal Wayamba Journal of Management, 7(1), pp.40-60.

Fama, E.F., 1970. Efficient capital markets: A review of theory and empirical work. The journal of Finance, 25(2), pp.383-417.

Fama, E.F., Fisher, L., Jensen, M.C. and Roll, R., 1969. The adjustment of stock prices to new information. International economic review, 10(1), pp.1-21. 
Fernando, C.S., Krishnamurthy, S. and Spindt, P.A., 1999. Is share price related to marketability? Evidence from mutual fund share splits. Financial Management, pp.54-67.

Garcia de Andoain, C. (2009). The Impact of Stock Split Announcements on Stock Price: A Test of Market Efficiency.

Gunathilaka, C. and Kongahawatte, S., 2011. Stock Splits in Sri Lanka: Valuation Effects \& Market Liquidity. In 8th International Conference on Business Management (pp. 90-94).

Hua, L. and Ramesh, S., 2013. A study on stock split announcements and its impact on stock prices in Colombo stock exchange (CSE) of Sri Lanka. Global Journal of Management and Business Research. 13(6), 25-34. Huang, G.C., Liano, K. and Pan, M.S., 2007. Liquidity changes around stock splits. Pennsylvania: Pennsylvania State System of Higher Education, Office of the Counselor.

Mackinlay, AC, 1997. Event studies in economics and finance. Journal of economic literature, 35(1), pp.13-39.

Marks, W 2006, What Is Undervalue or Overvalue of Stocks?, viewed 21 March 2021, <http:// https://finance.zacks.com/undervalue-overvalue-stocks2451.html>

Patel, M., Dave, M. and Shah, M., 2016. Stock price and liquidity effect of stock split: Evidence from Indian Stock Market. International Journal of Management Research and Reviews, 6(8), p.1030. 